\title{
IMPLEMENTASI PEMBELAJARAN AGAMA ISLAM BERBASIS MULTIMEDIA DI PONDOK PESANTREN
}

\author{
Unang Wahidin', Muhammad Sarbini ${ }^{2}$, Ali Maulida ${ }^{3}$, Miftah Wangsadanureja ${ }^{4}$ \\ ${ }^{1,2,3}$ STAI Al-Hidayah, ${ }^{4}$ Universitas Pelita Bangsa \\ email: unang.wahidin@gmail.com \\ email:sarbiniaas@gmail.com \\ email: alimaulida77@gmail.com \\ email:miftahwangsa@pelitabangsa.ac.id
}

\begin{abstract}
The objectives of this study were to: (1) obtain data related to multimedia support for Islamic religious learning materials; (2) describe the ease of obtaining multimedia that will be used in the learning process; (3) knowing mudarris skills in using multimedia; (4) knowing the availability of time to use multimedia; and (5) describe multimedia according to the students' level of thinking. The research method used is descriptive qualitative, with data collection techniques of observation, documentation and interviews. The results showed that: (1) multimedia provides convenience in achieving learning objectives; mastery of learning materials; convey the content of religious learning materials as a whole; able to transform abstract religious learning material into concrete; able to combine learning material to be concise; and clarify the information on the content of religious subject matter; (2) multimedia is an inexpensive learning medium; easy to get; easy to manufacture; and easy to use; (3) Islamic boarding school mudarris able to make multimedia for religious learning; able to use multimedia in religious learning; demonstrate the ability to operate multimedia well; and able to explain the advantages and disadvantages of using multimedia; (4) multimedia is able to streamline the delivery time of religious learning materials; able to repeat religious learning material on an ongoing basis; streamline the time of recording religious learning materials; can be used by students to study material outside class hours; presenting complex religious material to be simple; converting religious material that is too broad into the form of films / pictures; the delivery of religious material can be adjusted to the catching power of the students; and religious material that is too large becomes a simpler picture reality; (5) multimedia allows direct interaction between students and the real environment; completeness of learning can be realized; able to equalize the learning experience of students; generate the same perception of religious subject matter; the learning media presented are in accordance with the understanding ability of the students; able to encourage the motivation of students in studying religious material; able to condition the students to concentrate on following religious lessons; and able to bring the boarding school students friendly to technology.
\end{abstract}

Keyword: implementation, study, teaching, based, multimedia

\begin{abstract}
ABSTRAK
Tujuan penelitian ini adalah untuk: (1) mendapatkan data berkaitan dengan dukungan multimedia terhadap bahan pelajaran agama Islam; (2) mendeskripsikan kemudahan memperoleh multimedia yang akan digunakan dalam proses pembelajaran; (3) mengetahui keterampilan mudarris pondok pesantren dalam menggunakan multimedia; (4) mengetahui ketersediaan waktu untuk menggunakan multimedia; dan (5) mendeskripsikan multimedia sesuai dengan taraf berpikir santri. Metode penelitian yang digunakan adalah deskriptif kualitatif, dengan teknik pengumpulan data observasi, dokumentasi dan wawancara. Hasil penelitian menunjukan bahwa: (1) multimedia memberikan kemudahan dalam mencapai tujuan pembelajaran; penguasaan materi pembelajaran; menyampaikan isi materi pembelajaran keagamaan secara menyeluruh; mampu mengubah materi pembelajaran keagamaan yang
\end{abstract}


abstrak menjadi konkrit; mampu mengkombinasikan materi pembelajaran menjadi ringkas; dan memperjelas informasi isi materi pelajaran keagamaan; (2) multimedia merupakan media pembelajaran yang murah; mudah didapat; mudah dalam pembuatannya; dan mudah dalam penggunaannya; (3) mudarris pondok pesantren mampu membuat multimedia untuk pembelajaran keagamaan; mampu menggunakan multimedia pada pembelajaran keagamaan; menunjukan kemampuan mengoperasikan multimedia dengan baik; dan mampu menerangkan kelebihan dan kekurangan penggunaan multimedia; (4) multimedia mampu mengefisienkan waktu penyampaian materi pembelajaran keagamaan; mampu mengulang materi pembelajaran keagamaan secara berkelanjutan; mengefisienkan waktu pencatatan materi pembelajaran keagamaan; dapat digunakan santri untuk mempelajari materi di luar jam pelajaran; menyajikan materi keagamaan yang kompleks menjadi sederhana; mangubah materi keagamaan yang terlalu luas ke dalam bentuk film; penyampaian materi keagamaan dapat disesuaikan dengan daya tangkap santri; dan materi keagamaan yang terlalu besar menjadi realita gambar yang lebih simpel; (5) multimedia memungkinkan terjadi interaksi langsung antara santri dengan lingkungan kenyataan; ketuntasan belajar dapat diwujudkan; mampu menyamakan pengalaman belajar santri; menimbulkan persepsi yang sama terhadap materi pelajaran keagamaan; multimedia disajikan sesuai dengan kemampuan pemahaman santri; mampu mendorong motivasi santri dalam mempelajari materi keagamaan; mampu mengkondisikan santri untuk konsentrasi mengikuti pelajaran keagamaan; dan mampu membawa santri pondok pesantren bersahabat dengan teknologi.

Kata kunci: pelaksanaan, penelaahan, ajaran, berbasis, multimedia

\section{A. PENDAHULUAN}

Pembelajaran pada hakikatnya merupakan suatu usaha yang terencana dan dilakukan guru secara penuh kesadaran dalam rangka membantu peserta didik untuk memenuhi kebutuhannya akan pendidikan juga dapat membentuk kecakapan fundamental dan membantu sesorang agar cakap dalam melaksanakan tugas hidup (Saihu, 2020:130), sehingga terjadi proses belajar pada dirinya. Di dalam proses pembelajaran terjadi interaksi edukatif antara guru sebagai subjek yang mengajar dengan peserta didik sebagai subjek yang belajar sehingga terjadi proses pembelajaran yang efektif. Pembelajaran juga merupakan kegiatan yang bertujuan, baik tujuan yang sudah ditentukan oleh kurikulum maupun tujuan pembelajaran yang harus dicapai oleh peserta didik. Kedua tujuan tersebut terdokumentasikan secara tertulis berdasarkan tingkatan yang sudah ditetapkan. Pencapaian tujuan pembelajaran peserta didik meliputi aspek kognitif, aspek afektif, maupun aspek psikomotorik. Selain itu, ada beberapa kompetensi yang harus dicapai peserta didik yang meliputi kompetensi sikap spiritual, kompetensi sikap sosial, kompetensi pengetahuan, dan kompetensi keterampilan. Semuanya itu merupakan usaha untuk mempersiapkan peserta didik yang memiliki berbagai kemampuan dalam 
menjalani kehidupan yang lebih baik di masa datang.

Kegiatan pembelajaran pada pondok pesantren dilakukan oleh mudarris bersama santri. Pada pondok pesantren, mudarris sebagai guru atau pengajar adalah salah satu sumber belajar, pendidik, dan pengajar. Kata mudarris (المدرس ) dalam literatur Islam berasal dari Bahasa Arab, asal kata Darrasa (درس ) yang berarti mengajar, sedangkan kata mudarris sendiri bermakna pengajar atau guru. Hal ini sebagaimana tercantum dalam kamus Al-Munawwar Arab-Indonesia (A.W. Munawwir, 1997:398).

Mudarris memegang peranan sangat penting dalam mencapai tujuan pembelajaran santri di pondok pesantren. Tetapi kenyataannya masih terdapat kelemahan pendidikan pesantren, hal ini sebagaimana dikatakan Mujamil Qomar (2007:73) bahwa suasana pembelajaran yang pasif. Suasana yang demikian itu harus ditransformasikan ke dalam suasana pembelajaran yang kondusif dan memfasilitasi penguatan daya kritis para santri melalui berbagai kondisi dan pengembangan wawasan yang diperkuat oleh pendekatan-pendekatan metodologis.

Pembelajaran agama Islam di pondok pesantren seringkali dianggap kurang menarik bagi santri. Sebenarnya bukan karena materi pelajarannya tidak penting, tetapi kurang menariknya cara penyampaian materi agama Islam oleh mudarris. Sehingga dengan demikian mudarris pondok pesantren harus terus meningkatkan kompetensinya dalam mengelola komponen-komponen sistem pembelajaran. Salah satu komponen sistem pembelajaran yang harus dioptimalkan penggunaannya dalam proses pembelajaran adalah multimedia yang merupakan salah satu jenis dari komponen sistem pembelajaran yaitu media pembelajaran.

\section{B. TINJAUAN PUSTAKA}

\section{Implementasi}

Implementasi berasal dari bahasa Inggris "to implement" yang artinya mengimplementasikan. Implementasi bukan hanya suatu aktivitas, tetapi implementasi juga merupakan suatu kegiatan yang direncanakan serta dilaksanakan dengan serius dan mengacu pada norma-norma tertentu, guna mencapai tujuan kegiatan. Sedangkan Nana Sudjana (2009:20) memberikan pengertian implementasi dapat diartikan sebagai upaya pimpinan dengan menumbuhkan dorongan atau motivasi dalam dirinya untuk melakukan tugas atau kegiatan yang diberikan sesuai rencana, dan kemudian 
rencana tersebut dilaksanakan dengan mekanisme tertentu.

Dari beberapa pengertian tersebut dapat disimpulkan bahwa implementasi adalah penerapan atau pelaksanaan suatu kegiatan yang disusun secara terencana dengan mekanisme tertentu dan memerlukan keterampilan, kepemimpinan dan motivasi untuk mencapai tujuan yang diharapkan.

\section{Pembelajaran di Pondok Pesantren}

Pembelajaran atau sering disebut dengan instruksional merupakan konsepsi dari kegiatan belajar dan mengajar (Didi Supriadie \& Deni Darmawan, 2012:9). Kegiatan belajar di pondok pesantren dilakukan oleh santri sebagai subjek yang belajar dan kegiatan mengajar dilakukan oleh mudarris sebagai subjek yang mengajar. Kedua subjek ini melangsungkan interaksi edukatif dalam rangka untuk mencapai tujuan pembelajaran.

Pembelajaran di pondok pesantren sebagai satuan pendidikan jalur nonformal berlangsung sebagaimana pembelajaran di sekolah atau madrasah sebagai satuan pendidikan jalur formal, yang membedakan keduanya hanya pada bidang ilmu yang dipelajari. Adapun komponen-komponen sistem pembelajaran yang lain tetap digunakan karena kesemuanya terintegrasi menjadi satu kesatuan yang saling melengkapi dan saling mempengaruhi. Komponen-komponen sistem pembelajaran (Unang Wahidin, 2018:231) di pondok pesantren baik berupa (a) tujuan pembelajaran; (b) perencanaan pembelajaran; (c) santri sebagai subjek yang belajar; (d) mudarris sebagai subjek yang mendidik dan mengajar; (e) metode pembelajaran; (f) media pembelajaran; maupun (g) evaluasi pembelajaran, semuanya direncanakan, dilaksanakan dan dievaluasi pelaksanaannya dalam rangka untuk mencapai tujuan pembelajaran.

Sebagai Lembaga Pendidikan yang berbasis ke agamaan pondok pesantren memiliki empat ketentuan-ketentuan dan proses Pendidikan dan pembelajaran tersendiri hal ini sebagaimana disebutkan oleh Saihu dan Baeti Rohman (2019: 439).

\section{Pembelajaran Berbasis Multimedia}

Pembelajaran berbasis multimedia menghindarkan guru menggunakan metode pembelajaran konvensional yang bersifat verbalitas dan abstrak, sehingga proses pembelajaran berlangsung tidak menarik serta membosankan bagi peserta didik. Proses pembelajaran yang baik adalah yang memberikan kesempatan kepada peserta didik untuk dapat mengaktualisasikan dirinya dan terlibat secara maksimal dalam proses pembelajaran. Oleh karena itu pembelajaran berbasis multimedia yang di 
dalamnya memadukan teks, gambar, audio, musik, gambar animasi atau video akan mempermudah peserta didik memahami materi pembelajaran.

Multimedia merupakan gabungan dari berbagai media yang ada saat ini. Jika hal ini diterapkan dalam pembelajaran tentunya akan dapat membantu guru menciptakan suasana pembelajaran yang efektif dan efisien. Guru tidak perlu menghabiskan waktu menjelaskan secara lisan, tulisan atau gambar yang biasa dibuat di papan tulis, karena akan memakan waktu. Dalam pembelajaran yang menggunakan multimedia, guru akan selalu dituntut untuk kreatif dalam menemukan terobosanterobosan inovatif dalam pembelajaran untuk dapat memadukan teks, gambar, audio, musik, gambar animasi atau video dalam satu kesatuan yang saling mendukung guna mencapai tujuan pembelajaran yang mampu menimbulkan kegembiraan selama proses pembelajaran berlangsung (Saputra \& Purnama, 2015). Hal tersebut akan meningkatkan motivasi siswa selama proses belajar mengajar untuk memperoleh tujuan pembelajaran yang maksimal (Evan dan Umbara, 2021:8).

\section{METODE PENELITIAN}

Jenis penelitian ini merupakan penelitian lapangan dengan menggunakan pendekatan penelitian deskriptif kualitatif. Teknik pengumpulan data menggunakan observasi langsung untuk mengamati mudarris pondok pesantren melangsungkan proses pembelajaran berbasis multimedia. Adapun teknik dokumentasi digunakan untuk mengumpulkan data dari mudarris berupa manuskrip seperti perencanaan pembelajaran, tujuan pembelajaran, materi pembelajaran, jenis media pembelajaran yang digunakan dan evaluasi pembelajaran. Sedangkan teknik pengumpulan data melalui wawancara digunakan untuk menggali data dari mudarris yang berkaitan dengan pengetahuan dan keterampilannya dalam melaksanakan proses pembelajaran dengan menggunakan multimedia. Hal ini sebagaimana disampaikan Sugiyono (2009:194-195) bahwa wawancara digunakan sebagai teknik pengumpulan data apabila peneliti ingin mengetahui halhal dari responden yang lebih mendalam dan jumlah respondennya sedikit/kecil. Jumlah pertanyaan yang diwawancarakan dikelompokan ke dalam lima (5) variabel penelitian yang terdiri dari 30 indikator. Adapun variabel dengan indikatorindikatornya adalah sebagai berikut: (1) Variabel dukungan multimedia terhadap bahan pelajaran agama Islam terdiri dari enam indikator; (2) Variabel kemudahan memperoleh multimedia yang akan 
digunakan terdiri dari empat indikator; (3) Variabel keterampilan mudarris dalam menggunakan multimedia terdiri dari empat indikator; (4) Variabel ketersediaan waktu untuk menggunakan multimedia terdiri dari delapan indikator; dan (5) Variabel multimedia sesuai dengan taraf berpikir santri terdiri dari delapan indikator. 30 indikator inilah yang dijadikan pertanyaan dengan menggunakan teknik wawancara tertutup, dimana pilihan jawaban sudah ditentukan berupa skala dengan empat alternatif jawaban, yaitu: Sangat Tidak Setuju (STS) bernilai 1; Tidak Setuju (TS) bernilai 2; Setuju (S) bernilai 3; dan Sangat Setuju (SS) bernilai 4. Responden dalam penelitian ini adalah 14 orang mudarris yang mewakili lima (5) pondok pesantren dari empat (4) kecamatan di Kabupaten Bogor.

\section{PEMBAHASAN}

Data yang diperoleh dari hasil penelitian implementasi pembelajaran agama Islam berbasis multimedia di pondok pesantren dideskripsikan berdasarkan variabel beserta indikatornya yang dijadikan pertanyaan saat wawancara kepada 14 orang mudarris yang menjadi responden, adapun datanya sebagai berikut:

1. Dukungan multimedia terhadap bahan pembelajaran agama Islam
Data dukungan multimedia terhadap bahan pembelajaran agama Islam sebagaimana tergambar pada diagram batang di bawah ini:

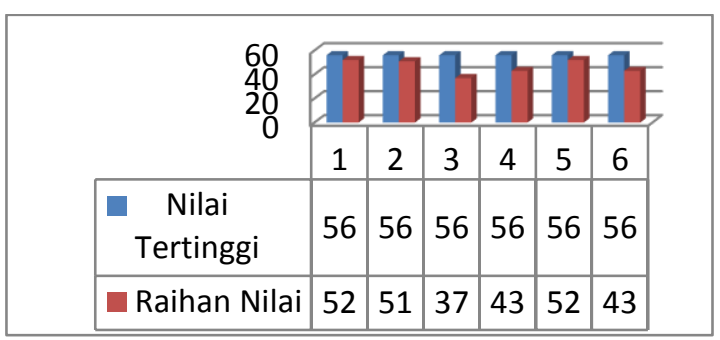

Berdasarkan data yang diperoleh dan digambarkan pada diagram batang di atas menunjukan bahwa dukungan multimedia terhadap bahan pembelajaran agama Islam memberikan kontribusi yang besar. Hal ini ditunjukan berdasarkan jawaban 14 mudarris pondok pesantren sebagai responden terhadap enam (6) pertanyaan yang diberikan. Jawaban mudarris pondok pesantren tersebut secara berurutan adalah sebagai berikut: (1) multimedia memberikan kemudahan dalam mencapai tujuan pembelajaran; (2) multimedia memberikan kemudahan dalam penguasaan materi pembelajaran; (3) multimedia menyampaikan isi materi pembelajaran keagamaan secara menyeluruh; multimedia mampu mengubah materi pembelajaran keagamaan yang abstrak menjadi konkrit; (5) multimedia mampu mengkombinasikan materi pembelajaran menjadi ringkas; dan (6) multimedia 
memperjelas informasi isi materi pelajaran keagamaan.

Uraian di atas memberikan gambaran bahwa multimedia memberikan dukungan terhadap bahan pembelajaran. Penggunaan multimedia dalam proses pembelajaran dapat memberikan kemudahan bagi peserta didik dalam mencapai tujuan pembelajaran dan penguasaan materi pembelajaran, isi materi pembelajaran tersampaikan secara menyeluruh, mengubah materi pembelajaran yang abstrak menjadi konkrit, mengkombinasikan materi pembelajaran menjadi ringkas, dan multimedia dapat memperjelas informasi isi materi pelajaran. Hal ini sesuai dengan yang disampaikan Azhar Arsyad (2004:172), bahwa multimedia bertujuan untuk menyajikan informasi dalam bentuk yang menyenangkan, menarik, mudah dimengerti, dan jelas. Informasi akan mudah dimengerti karena sebanyak mungkin indera, terutama telinga dan mata, digunakan untuk menyerap informasi.

2. Kemudahan memperoleh multimedia yang akan digunakan

Data kemudahan memperoleh multimedia yang akan digunakan mudarris pondok pesantren dalam proses pembelajaran sebagaimana tergambar pada diagram batang di bawah ini:

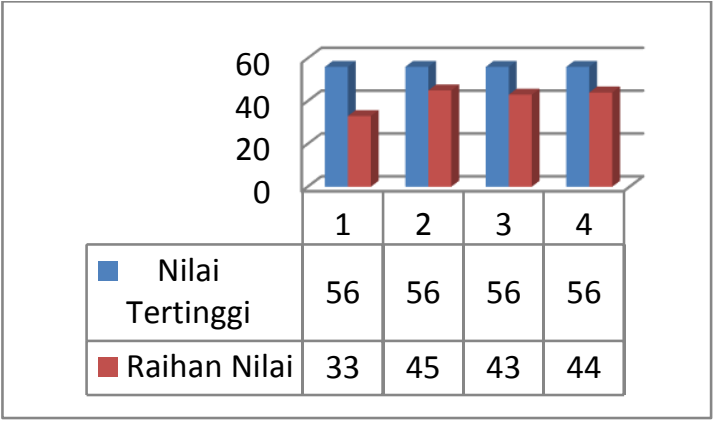

Diagram batang di atas menunjukan bahwa 14 mudarris pondok pesantren sebagai responden menjawab empat (4) pertanyaan yang diberikan dengan menyatakan bahwa terdapat kemudahan dalam memperoleh multimedia yang akan digunakan. Jawaban mudarris tersebut secara berurutan adalah sebagai berikut: (1) multimedia merupakan media pembelajaran yang murah; (2) multimedia merupakan media pembelajaran yang mudah didapat; (3) multimedia merupakan media pembelajaran yang mudah dalam pembuatannya; dan (4) multimedia merupakan media pembelajaran yang mudah dalam penggunaannya.

Berkaitan dengan uraian di atas, bahwa saat ini terdapat kemudahan untuk memperoleh multimedia yang akan digunakan dalam proses pembelajaran. Dimana dalam dunia pendidikan saat ini, komputer sebagai basis utama multimedia yang di dalam sistemnya mengkombinasikan grafik, teks, suara, gambar, video, dan animasi dapat menampilkan informasi, pesan serta isi 
materi pembelajaran. Dengan demikian penggunaan multimedia dalam proses pembelajaran menjadi lebih murah, mudah didapatkan, mudah dalam pembuatannya serta mudah dalam penggunaannya. Hal ini senada dengan apa yang disampaikan Cecep Kustandi dan Daddy Darmawan (2020:197) yang mengarahkan pengertian multimedia kepada perkembangan komputer yang pada saat ini berkembang sangat pesat dan juga sangat membantu dalam dunia pendidikan.

3. Keterampilan mudarris pondok pesantren dalam menggunakan multimedia

Data keterampilan mudarris pondok pesantren dalam menggunakan multimedia sebagaimana tergambar pada diagram batang di bawah ini:

\begin{tabular}{|c|c|c|c|c|}
\hline & \multicolumn{4}{|c|}{$\sqrt{4}=$} \\
\hline & 1 & 2 & 3 & 4 \\
\hline $\begin{array}{c}\text { Nilai } \\
\text { Tertinggi }\end{array}$ & 56 & 56 & 56 & 56 \\
\hline Raihan Nilai & 46 & 47 & 49 & 48 \\
\hline
\end{tabular}

Berdasarkan data pada diagram batang tersebut di atas, dapatlah dikatakan bahwa terdapat keterampilan yang cukup pada mudarris pondok pesantren dalam menggunakan multimedia pada proses pembelajaran. Hal ini berdasarkan jawaban mudarris pondok pesantren terhadap pertanyaan yang diberikan sesuai dengan nomor urut sebagai berikut: (1) mudarris pondok pesantren menunjukan kemampuan membuat multimedia untuk pembelajaran keagamaan; (2) mudarris pondok pesantren menunjukan pemahaman yang baik dalam menggunakan multimedia pada pembelajaran keagamaan; (3) mudarris pondok pesantren menunjukan kemampuan mengoperasikan multimedia dengan baik dalam pembelajaran keagamaan; dan (4) mudarris pondok pesantren mampu menerangkan kelebihan dan kekurangan penggunaan multimedia.

Guru saat ini dituntut untuk dapat mengenal, memahami, terampil mengoperasikan, bahkan mampu membuat jenis media pembelajaran tertentu . Hal ini disebabkan karena media pembelajaran merupakan salah satu komponen dari sistem pembelajaran yang terintegrasi dan tidak bisa dipisahkan dari komponen sistem pembelajaran lainnya (Unang Wahidin, 2018:231). Salah satu media pembelajaran yang bisa digunakan dalam proses pembelajaran adalah multimedia. Cecep Kustandi dan Daddy Darmawan (2020:197) mengatakan bahwa jika dibandingkan dengan informasi dalam bentuk teks (huruf dan angka) yang umumnya terdapat pada komputer saat ini, tentu informasi dalam bentuk multimedia yang dapat diterima dengan kedua indra penglihatan manusia 
dalam bentuk yang sesuai dengan aslinya atau dalam dunia yang sesungguhnya akan lebih menarik dan memperkaya pengalaman bagi penggunanya.

4. Ketersediaan waktu untuk menggunakan multimedia

Data ketersediaan waktu untuk menggunakan multimedia sebagaimana tergambar pada diagram batang di bawah ini:

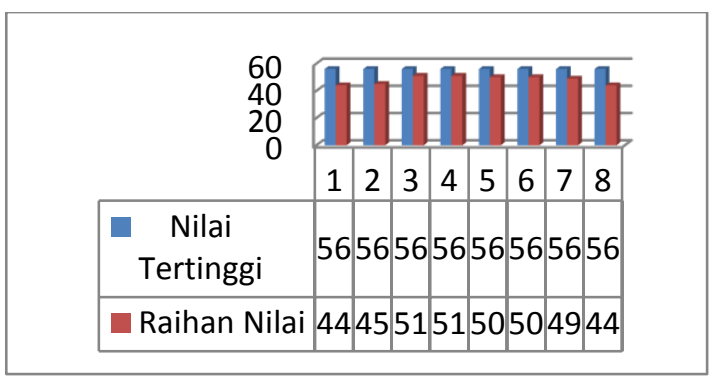

Berdasarkan data pada diagram batang tersebut di atas, terlihat bahwa terdapat ketersediaan waktu bagi mudarris untuk menggunakan multimedia pada proses pembelajaran di pondok pesantren. Hal ini berdasarkan jawaban mudarris pondok pesantren yang menjadi responden penelitian. Adapun jawaban mudarris pondok pesantren terhadap pertanyaan yang diberikan sesuai dengan nomor urut adalah sebagai berikut: (1) multimedia merupakan media pembelajaran yang mampu mengefisienkan waktu penyampaian materi pembelajaran keagamaan; (2) multimedia merupakan media pembelajaran yang mampu mengulang materi pembelajaran keagamaan secara berkelanjutan; multimedia merupakan media pembelajaran yang mengefisienkan waktu pencatatan materi pembelajaran keagamaan; multimedia merupakan media pembelajaran yang dapat digunakan santri untuk mempelajari materi di luar jam pelajaran; (5) multimedia menyajikan materi keagamaan yang kompleks menjadi sederhana; (6) multimedia mampu mangubah materi keagamaan yang terlalu luas ke dalam bentuk film; (7) multimedia mengkondisikan kapasitas kecepatan penyampaian materi keagamaan dapat disesuaikan dengan daya tangkap santri; dan (8) multimedia menjadikan materi keagamaan yang terlalu besar menjadi realita gambar yang lebih simpel.

Berdasarkan uraian di atas dapatlah dikatakan bahwa, multimedia merupakan media pembelajaran yang mampu mengefisienkan waktu penyampaian materi pembelajaran, mampu mengulang materi pembelajaran, mengefisienkan waktu pencatatan materi pembelajaran, dapat digunakan untuk mempelajari materi di luar jam pelajaran, menyajikan materi yang kompleks menjadi sederhana, mangubah materi pelajaran yang terlalu luas ke dalam bentuk film, kecepatan penyampaian materi pelajaran dapat disesuaikan dengan daya tangkap peserta didik, dan materi pelajaran yang terlalu besar menjadi realita gambar 
yang lebih simpel. Sehingga dengan demikian penggunaan multimedia dalam proses pembelajaran dapat mempermudah penguasaan materi pembelajaran oleh peserta didik, yang pada akhirnya mempercepat pencapaian tujuan pembelajaran.

5. Multimedia sesuai dengan taraf berpikir santri pondok pesantren

Data multimedia sesuai dengan taraf berpikir santri sebagaimana tergambar pada diagram batang di bawah ini:

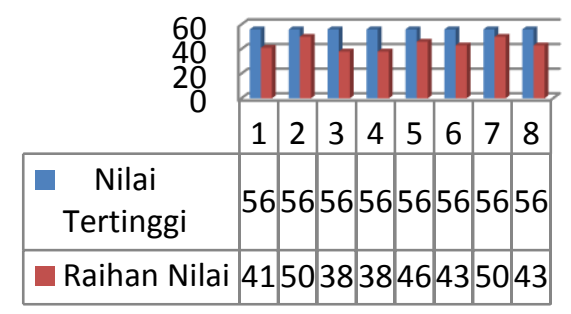

Diagram batang tersebut di atas menunjukan bahwa penggunaan multimedia pada proses pembelajaran sesuai dengan taraf berpikir santri pondok pesantren. Hal ini berdasarkan jawaban dari pertanyaan yang disampaikan kepada mudarris pondok pesantren. Adapun jawaban mudarris pondok pesantren adalah sebagai berikut: (1) dengan menggunakan multimedia memungkinkan terjadi interaksi langsung antara santri dengan lingkungan kenyataan; (2) multimedia memungkinkan santri pondok pesantren belajar mandiri sehingga ketuntasan belajar dapat diwujudkan; (3) multimedia mampu menyamakan pengalaman belajar santri; (4) multimedia menimbulkan persepsi yang sama terhadap materi pelajaran keagamaan; (5) multimedia merupakan media pembelajaran yang disajikan sesuai dengan kemampuan pemahaman santri; multimedia merupakan media pembelajaran yang mampu mendorong motivasi santri dalam mempelajari materi keagamaan; (7) multimedia merupakan media pembelajaran yang mampu mengkondisikan santri untuk konsentrasi mengikuti pelajaran keagamaan; dan (8) multimedia merupakan media pembelajaran yang mampu membawa santri pondok pesantren bersahabat dengan teknologi.

Memperhatikan uraian di atas, dapatlah disimpulkan bahwa penggunaan multimedia dalam proses pembelajaran memungkinkan terjadi interaksi langsung antara peserta didik dengan lingkungan kenyataan, ketuntasan belajar peserta didik dapat diwujudkan, menyamakan pengalaman belajar peserta didik, menimbulkan persepsi yang sama terhadap materi pelajaran, multimedia merupakan jenis media pembelajaran yang sesuai dengan kemampuan pemahaman peserta didik, mampu mendorong motivasi peserta didik dalam mempelajari materi pembelajaran, mampu mengkondisikan 
peserta didik untuk konsentrasi mengikuti pelajaran, dan mampu membawa peserta didik bersahabat dengan teknologi. Menurut Cecep Kustandi dan Bambang Sutjipto (2011:78) kelebihan dari multimedia ini adalah memberikan kemudahan kepada peserta didik untuk belajar secara individual maupun secara kelompok. Selain itu, memberikan kemudahan bagi guru dalam menyampaikan materi pembelajaran.

\section{E. KESIMPULAN}

Implementasi pembelajaran agama Islam berbasis multimedia di pondok pesantren melibatkan berbagai komponen pembelajaran, baik berupa perencanaan sistem pembelajaran, penentuan tujuan pembelajaran, mudarris sebagai subjek yang mengajar, santri sebagai subjek yang belajar, penggunaan metode dan media pembelajaran, serta melakukan evaluasi pembelajaran.

Implementasi pembelajaran agama Islam berbasis multimedia agar dapat berjalan dengan baik, maka penggunaan multimedia harus dapat mendukung terhadap bahan pembelajaran agama Islam, kemudahan memperoleh multimedia yang akan digunakan, keterampilan mudarris pondok pesantren dalam menggunakan multimedia, ketersediaan waktu untuk menggunakan multimedia, dan multimedia yang digunakan harus sesuai dengan taraf berpikir santri pondok pesantren. Dengan demikian diharapkan multimedia yang digunakan mudarris dalam proses pembelajaran agama Islam di pondok pesantren, dapat mempermudah santri dalam mencapai tujuan pembelajaran yang sudah direncanakan.

\section{DAFTAR PUSTAKA}

\section{Sumber dari Jurnal dan Penelitian}

Puadi, Wahyu, Farhan, Evan. dan Umbara, Uba. (2021). Implementasi Pembelajaran Berbasis Multimedia Terhadap Kemampuan Representasi Matematika. SJME: Supremum Journal of Mathematics Education, 5(1): 8.

Saihu dan Baeti Rohman. (2019). Pembentukan Karakter Melalui Model Pendidikan Transformatife Learning pada Santri di pondok Pesantren Nurul Ikhlas Bali. Edukasi Islami: Jurnal Pendidikan Islam, 08(02).

Saihu. (2020). Pendidikan Sosial yang Terkandung dalam Surat At-Taubah Ayat 71-72. Edukasi Islami: Jurnal Pendidikan Islam, 09(01).

Saputra, W., \& Purnama, B. E. (2015). Pengembangan multimedia pembelajaran interaktif untuk mata kuliah organisasi komputer. SpeedSentra Penelitian Engineering dan Edukasi, 4(2).

Wahidin, Unang. (2018). Implementasi Literasi Media dalam Proses Pembelajaran Pendidikan Agama Islam dan Budi Pekerti. Edukasi Islami: Jurnal Pendidikan Islam, 7(02): 231. 


\section{Sumber dari Buku}

Kustandi, Cecep dan Darmawan, Daddy. (2020). Pengembangan Media Pembelajaran. Konsep dan Aplikasi Pengembangan Media Pembelajaran bagi Pendidik di Sekolah dan Masyarakat. Jakarta: Kencana.

Kustandi, Cecep dan Sutjipto, Bambang. (2011). Media Pembelajaran, Manual dan Digital. Bogor: Ghalia Indonesia.

Sudjana, Nana. (2009). Dasar-Dasar Proses Belajar Mengajar. Bandung: Sinar Baru.
Sugiyono. (2009). Metode Penelitian Pendidikan. Pendekatan Kuantitatif. Kualitatif. $R \& D$. Bandung: Alfabeta.

Supriadie, Didi \& Darmawan, Deni. (2012). Komunikasi Pembelajaran. Bandung: PT Remaja Rosdakarya.

Qomar, Mujamil. (2007). Strategi Baru Pengelolaan Lembaga Pendidikan Islam. Manajemen Pendidikan Islam. Jakarta: Erlangga.

Munawwir, W., A. (1997). Kamus AlMunawwir Arab-Indonesia Terlengkap. Surabaya: Pustaka Progressif. 